\title{
Menyibak Hak Konstitusional yang Tersembunyi
}

\author{
Bisariyadi \\ Mahkamah Konstitusi Republik Indonesia \\ Jln. Medan Merdeka Barat No. 6 Jakarta \\ bisariyadi@mahkamahkonstitusi.go.id
}

Received: 23 Mei 2017; Accepted: 19 Januari 2018; Published: 5 Juni 2018

DOI: 10.20885/iustum.vol24.iss4.art1

\begin{abstract}
The Constitutional Court has established the rights to legal aid and to presumption of innocence as constitutional rights. However, these two rights are not included in the 1945 Constitution. This study aimed to know the reasons why the Constitutional Court decided to include these rights as constitutional rights and the purposive approach used. This study used normative research methods that focused on library study. This study revealed that the establishment of these implied rights, namely the rights to legal aid and to presumption of innocence, as constitutional rights is an effort to protect the rights of citizens within the framework of the rule of law. In the future, this kind of establishment might occur more often given that Indonesia has already had rules on Human Rights in the form of laws and ratified international conventions related to fundamental rights.
\end{abstract}

Keywords: Constitutional right; implied right; constitutional court

\section{Abstrak}

Mahkamah Konstitusi menetapkan hak untuk memperoleh bantuan hukum dan hak atas praduga tak bersalah sebagai hak konstitusional. Padahal, kedua hak tersebut tidak tercantum dalam UUD 1945. Tujuan penelitian ini adalah untuk mengetahui latar belakang Mahkamah Konstitusi mengangkat hak tersebut menjadi hak konstitusional serta pendekatan penafsiran yang digunakan. Penelitian menggunakan metode penelitian normatif yang menitikberatkan pada studi kepustakaan. Penelitian ini menemukan bahwa penetapan hak yang tersirat, yaitu hak untuk memperoleh bantuan hukum dan hak atas praduga tak bersalah, sebagai hak konstitusional merupakan upaya memberi kepastian pada perlindungan hak warga negara dalam kerangka negara hukum. Penyingkapan hak yang tersirat akan menjadi lebih banyak lagi di masa yang akan datang mengingat bahwa Indonesia telah memiliki aturan mengenai Hak Asasi Manusia dalam bentuk undang-undang serta meratifikasi konvensi internasional yang berkaitan dengan hak-hak fundamental.

Kata-kata Kunci: Hak konstitusional; hak yang tersirat; mahkamah konstitusi 


\section{Pendahuluan}

Keberadaan Mahkamah Konstitusi (MK) sebagai penafsir Undang-Undang Dasar (UUD) membawa implikasi besar terhadap perubahan, terutama dalam hal perlindungan hak warga negara. Tidak sedikit di antara putusan MK yang diterbitkan dalam rangka melindungi hak-hak konstitusional warga negara juga membawa pengaruh kepada perubahan sistem politik. Misalnya, dalam rangka memberi jaminan atas pelaksanaan hak warga negara untuk memberikan suara dalam pemilihan umum, MK mengubah aturan mekanisme pemberian suara di Tempat Pemungutan Suara bagi warga yang tidak terdaftar dalam Daftar Pemilih Tetap (DPT). ${ }^{1}$ Kemudian, MK juga menetapkan penyelenggaraan pemilu legislatif dan pemilu presiden secara serentak dengan pertimbangan, salah satunya adalah memberikan kesempatan warga negara untuk melaksanakan hak memilih secara cerdas. ${ }^{2}$ Kedua contoh putusan di atas adalah dalam konteks memberi perlindungan kepada hak memilih warga negara. Dalam hal pendidikan, untuk melindungi hak konstitusional warga negara memperoleh pendidikan, MK memastikan bahwa anggaran pendidikan yang dialokasikan dalam Anggaran Pendapatan dan Belanja Negara (APBN) tiap tahunnya harus memenuhi syarat konstitusional sekurang-kurangnya $20 \% .^{3}$

Dalam menguji konstitusionalitas Undang-Undang (UU), MK selalu mempertimbangkan ada/tidaknya kerugian konstitusional yang diderita pemohon. Artinya, pemohon harus dapat menjelaskan hak-hak konstitusional yang dilanggar dengan berlakunya UU. Yang dimaksudkan dengan hak konstitusional adalah "hak-hak yang diatur dalam UUD 1945". 4 Di Indonesia, terdapat pembedaan antara hak konstitusional (constitutional rights) dengan hak-

${ }_{1}^{1}$ Putusan MK Nomor 102/PUU-VII/2009 tentang Pengujian Undang-Undang Nomor 42 Tahun 2008 tentang Pemilihan Umum Presiden dan Wakil Presiden (Untuk perlindungan hak pemilih dalam Pemilihan Presiden dan Wakil Presiden); Lihat juga Putusan MK Nomor 85/PUU-X/2012 tentang Pengujian UndangUndang Nomor 32 Tahun 2004 tentang Pemerintahan Daerah (Untuk perlindungan hak pemilih dalam Pemilihan Kepala Daerah)

2 Putusan MK Nomor 14/PUU-XI/2013 tentang Pengujian Undang-Undang Nomor 42 Tahun 2008 tentang Pemilihan Umum Presiden dan Wakil Presiden, Paragraf [3.17]

3 Terdapat beberapa Putusan MK yang menguji konstitusionalitas alokasi anggaran pendidikan sekurangkurangnya 20\% dari APBN, yaitu Putusan MK Nomor 012/PUU-III/2005; Putusan MK Nomor 026/PUUIII/2005; Putusan MK Nomor 026/PUU-IV/2006; Putusan MK Nomor 24/PUU-V/2007; dan Putusan MK Nomor 13/PUU-VI/2008

4 Penjelasan Pasal 51 ayat (1) UU Nomor 8 Tahun 2011 tentang Perubahan UU Nomor 24 Tahun 2003 tentang Mahkamah Konstitusi, LNRI Tahun 2011 Nomor 70, TLNRI Nomor 5226. 
hak yang lain yang tercantum dalam UU (statutory rights). Jimly Asshiddiqie membedakan antara hak asasi yang diadopsi dalam UUD 1945 sebagai hak konstitusional sedangkan hak-hak yang diatur secara lebih rinci dan operasional dalam peraturan perundang-undangan sebagai hak (legal rights) dan bukanlah termasuk dalam hak konstitusional. ${ }^{5}$

Perbedaan tersebut juga dapat dilihat dari lingkup kewenangan dalam materi pengujian peraturan perundang-undangan. Dalam perkara pengujian UU terhadap UUD yang menjadi kewenangan MK, pemohon harus membuktikan adanya kerugian "hak konstitusional", ${ }^{6}$ sedangkan dalam perkara pengujian peraturan perundang-undangan di bawah UU yang menjadi kewenangan Mahkamah Agung (MA), pemohon harus menjelaskan adanya kerugian "hak".7 Kerugian hak itu dielaborasi dalam ukuran kriteria yang telah ditetapkan dalam beberapa putusan MA di mana menurut MA kerugian hak harus memenuhi unsur adanya hak pemohon yang diberikan oleh peraturan perundang-undangan. ${ }^{8}$

Meskipun demikian, MK dalam beberapa putusan dengan sengaja mengangkat status suatu hak sebagai batu uji dalam perkara pengujian UU. Dengan kata lain, MK mempertimbangkan hak yang tidak tercantum dalam konstitusi sebagai hak konstitusional. Hak demikian, dalam tradisi common law terutama di Amerika Serikat dan Australia dikenal dengan istilah "implied rights" atau "unenumerated rights". Sedangkan dalam tradisi civil law, kajian mengenai hal ini sangat terbatas, namun bukan berarti tidak ada, seperti yang dipraktekkan di Mahkamah Konstitusi Korea Selatan.

Paling tidak ada dua hak di mana MK dalam putusannya menjadikannya sebagai hak konstitusional, yaitu "hak untuk memperoleh bantuan hukum" dan "hak atas praduga tak bersalah". Kedua hak ini tidak disebutkan secara jelas dalam

\footnotetext{
${ }^{5}$ Jimly Asshiddiqie, "Hak Konstitusional Perempuan dan Tantangan Penegakannya", Makalah pada Dialog Publik dan Konsultasi Nasional "Perempuan dan Konstitusi di Era Otonomi Daerah: Tantangan dan Penyikapan Bersama” diselenggarakan oleh Komnas Perempuan, Jakarta, 27 Nopember 2007, hlm. 1-2

${ }^{6}$ Lihat Pasal 51 ayat (1) UU Nomor 8 Tahun 2011 tentang Perubahan UU Nomor 24 Tahun 2003 tentang Mahkamah Konstitusi.

7 Lihat Pasal 31A ayat (2) UU Nomor 3 Tahun 2009 tentang Perubahan Kedua Atas Undang-Undang Nomor 14 Tahun 1985 tentang Mahkamah Agung, Tahun 2009 Nomor 3, TLNRI Nomor 4958.

${ }^{8}$ Lihat Putusan Mahkamah Agung Nomor: 54 P/HUM 2013, tanggal 19 Desember 2013; Putusan Nomor : 62 P/HUM/2013, tanggal 18 Nopember 2013; Putusan Nomor 64 P/HUM/2013; dan Putusan Nomor 11 $\mathrm{P} / \mathrm{HUM} / 2014$
} 
UUD 1945. Oleh karenanya, penelitian ini menitikberatkan pada praktek menggunakan hak konstitusional yang tersirat dalam UUD.

\section{Rumusan Masalah}

Permasalahan yang diangkat dalam penelitian ini adalah mengenai pertama, apa latar belakang yang mendorong MK untuk menggunakan hak yang tersirat sebagai batu uji dalam perkara pengujian?; Kedua, pendekatan penafsiran apa yang dilakukan MK hingga sampai pada kesimpulan untuk menetapkan suatu hak sebagai sebagai hak konstitusional yang tersirat dalam UUD?.

\section{Tujuan Penelitian}

Penelitian ini bertujuan untuk mencari maksud dari MK untuk mengangkat derajat suatu hak menjadi hak konstitusional serta mencari tahu pendekatan penafsiran yang menjadi pertimbangan MK untuk menetapkan suatu hak sebagai hak yang tersirat dalam konstitusi.

\section{Metode Penelitian}

Kajian ini merupakan penelitian normatif yang menitikberatkan pada studi kepustakaan, terutama dengan menggali putusan-putusan MK yang menetapkan suatu hak sebagai hak konstitusional. Penelitian ini akan mengkaji Putusan MK Nomor 006/PUU-II/2004 tentang Pengujian Undang-Undang Nomor 18 Tahun 2003 tentang Advokat dan Putusan MK Nomor 133/PUU-VII/2009 tentang Pengujian Undang-Undang Nomor 30 Tahun 2002 tentang Komisi Pemberantasan Tindak Pidana Korupsi, meskipun tidak terbatas hanya pada kedua putusan tersebut. Selain itu, penelitian ini juga akan melihat pada praktek serupa yang terdapat pada putusan Mahkamah Agung Australia (Australian High Court), putusan Mahkamah Agung Amerika Serikat (Supreme Court of the United States, SCOTUS) serta putusan Mahkamah Konstitusi Korea Selatan. 


\section{Hasil Penelitian dan Pembahasan}

\section{Perbedaan Hak Asasi Manusia dan Hak Konstitusional}

Salah satu fungsi konstitusi adalah sebagai guardian of fundamental rights. ${ }^{9}$ Oleh karenanya, pemuatan hak asasi manusia dalam konstitusi sebuah negara memiliki arti penting dalam rangka menciptakan keseimbangan antara penyelenggaraan kekuasaan dalam negara dan melindungi hak-hak dasar warga negara. ${ }^{10}$ Pemerintah sebagai pemegang kekuasaan negara tidak dapat bertindak sewenang-wenang terhadap warga negara, karena sesungguhnya seluruh warga negara merupakan rakyat yang memegang kedaulatan tertinggi. Tarik ulur kekuasaan antara pemegang kedaulatan dan penerima mandat kekuasaan perlu diatur dalam konstitusi. Rakyat sebagai pemegang kedaulatan memiliki jaminan perlindungan atas hak-hak dasarnya sedangkan pemerintah yang menjalankan kekuasaan harus tercatat secara jelas kewenangan yang dimilikinya. Kesemuanya itu harus tercantum dalam konstitusi.

Dari sejumlah hak yang telah dicantumkan dalam Undang-Undang Dasar Negara Republik Indonesia Tahun 1945, ternyata tidak semua hak asasi manusia tercakup di dalamnya. Ada hak-hak yang dengan sengaja tidak dimasukkan dalam konstitusi. Dari sudut pandang penggunaan istilah, "hak asasi manusia" dan "hak konstitusional" memang berbeda dalam hal ruang lingkup. Hak asasi manusia yang tercantum dalam konstitusi disebut sebagai hak konstitusional. Oleh karenanya, hak asasi manusia tidaklah identik dengan hak konstitusional sebab tidak semua hak asasi manusia tercantum dalam Undang-Undang Dasar. Namun sebaliknya, setiap hak konstitusional pastilah hak asasi manusia. Di Indonesia, terdapat beragam hak yang merupakan hak asasi yang dicantumkan dalam UU.11 Begitu juga, hak asasi yang tercantum dalam UU sebagai hasil ratifikasi instrumen internasional. 12

\footnotetext{
9 Bagir Manan dan Susi Dwi Harijanti, "Konstitusi dan Hak Asasi Manusia”, artikel dalam Padjadjaran Jurnal Ilmu Hukum, Vol. 3, No. 3, 2016, hlm. 456

10 Sri Soemantri, Bunga Rampai Hukum Tata Negara Indonesia, Alumni, Bandung, 1992, hlm. 74.

${ }^{11}$ Lihat UU Nomor 39 Tahun 1999 tentang Hak Asasi Manusia, LNRI Tahun 1999 Nomor 165, TLNRI Nomor 3886; dan UU Nomor 26 Tahun 2000 tentang Pengadilan Hak Asasi Manusia, LNRI Tahun 2000 Nomor 208, TLNRI Nomor 4026.

12 Beberapa UU yang meratifikasi konvensi internasional berkaitan dengan perlindungan hak asasi adalah:

- UU Nomor 11 Tahun 2005 tentang Pengesahan International Covenant On Economic, Social And Cultural Rights
} 
Penggunaan istilah "hak asasi manusia" memiliki spektrum yang universal dengan cakupan yang lebih luas dibandingkan istilah "hak konstitusional”. Hak konstitusional memiliki lingkup domestik yang berlaku dalam hukum positif sebuah negara. Perkembangan hak asasi manusia di tingkat internasional memberi dorongan bagi pengakuan keberadaannya di tingkat nasional sebagai hak konstitusional. ${ }^{13}$

Namun demikian, bukan berarti bahwa di keduanya terdapat garis batas dikotomis. Hak asasi manusia dan hak konstitusional memiliki kesamaan fungsi, substansi dan struktur. ${ }^{14}$ Fungsi dari keberadaan keduanya adalah untuk membatasi kekuasaan pemerintah serta melindungi hak-hak dasar setiap warga negara. ${ }^{15}$ Secara substantif, keduanya memuat hak-hak dasar seperti hak sipil dan politik, hak ekonomi, sosial dan budaya, selain perlindungan terhadap hak-hak atas kelompok minoritas dan perlindungan lingkungan. ${ }^{16}$ Selain itu, keduanya juga memiliki kesamaan struktur di mana terdapat pembedaan antara hak-hak yang dapat dibatasi (derogable) dan tidak dapat dibatasi (non-derogable) atau dikurangi unsur pemenuhannya. ${ }^{17}$

(Kovenan Internasional Tentang Hak-Hak Ekonomi, Sosial Dan Budaya), LNRI Tahun 2005 Nomor 118, TLNRI Nomor 4557;

- UU Nomor 12 Tahun 2005 tentang Pengesahan International Covenant On Civil And Political Rights (Kovenan Internasional Tentang Hak-Hak Sipil Dan Politik), LNRI Tahun 2005 Nomor 119, TLNRI Nomor 4558;

- UU Nomor 29 Tahun 1999 tentang Pengesahan International Convention On The Elimination Of All Forms Of Racial Discrimination 1965 (Konvensi Internasional Tentang Penghapusan Segala Bentuk Diskriminasi Rasial 1965), LNRI Tahun 1999 Nomor 83, TLNRI Nomor 3852;

- UU Nomor 7 Tahun 1984 tentang Pengesahan Konvensi Mengenai Penghapusan Segala Bentuk Diskiriminasi Terhadap Wanita (Convention On The Elimination Of All Forms OfDiscrimination Against Women), LNRI Tahun 1984 Nomor 29, TLNRI Nomor 3227;

- UU Nomor 6 Tahun 2012 tentang Pengesahan International Convention On The Protection Of The Rights Of All Migrant Workers And Members OfTheir Families (Konvensi Internasional Mengenai Perlindungan Hak-Hak Seluruh Pekerja Migran Dan Anggota Keluarganya), LNRI Tahun 2012 Nomor 115, TLNRI Nomor 5314;

- UU Nomor 19 Tahun 2011 tentang Pengesahan Convention On The Rights Of Persons With Disabilities (Konvensi Mengenai Hak-Hak Penyandang Disabilitas), LNRI Tahun 2011 Nomor 107, TLNRI Nomor 5251.

${ }^{13}$ I Dewa Gede Palguna, Pengaduan Konstitusional: Upaya Hukum Terhadap Pelanggaran Hak-Hak Konstitusional Warga Negara, Penerbit Sinar Grafika, Jakarta, 2013, hlm. 131.

14 Stephen Gardbaum, "Human Rights as International Constitutional Rights", artikel dalam The European Journal of International Law, Vol 19, no. 4, 2008, hlm. 750-751

${ }^{15}$ Gerald L. Neuman, "Human Rights and Constitutional Rights: Harmony and Dissonance", artikel dalam Stanford Law Review, Vol. 55, No. 5, 2003, hlm. 1863,

${ }^{16}$ Gardbaum., Op. Cit., hlm 750. Sebagai catatan, materi muatan yang terkandung dalam hak asasi biasanya lebih rinci dibandingkan dengan hak konstitusional. Penyusun konstitusi kerap memilih memuat hak-hak dengan menggunakan bahasa yang lebih umum demi fleksibilitas keberlakuan konstitusi dan membuka kemungkinan penafsiran dari makna tersebut dibandingkan harus mengubah/mengamendemen konstitusi untuk memuat atau mengubah hak yang telah/akan dicantumkan dalam konstitusi.

17 Stephen Gardbaum, “The 'Horizontal' Effect of Constitutional Rights", artikel dalam Michigan Law Review, Vol. 102, 2003, hlm. 387 
Perlindungan hak asasi dan hak konstitusional di era globalisasi menuntut adanya penyesuaian. ${ }^{18}$ Misalnya, penggunaan mesin pencari (search engine) di internet, seperti Google, yang berkemampuan menyimpan data pribadi pengguna berkaitan langsung dengan hak konstitusionalnya atas perlindungan data-data pribadi dan kebebasan berekspresi. Fungsi mesin pencari di internet untuk memfasilitasi pencarian data tidaklah sama artinya dengan membuka informasi yang berisi data-data pribadi pengguna. ${ }^{19}$ Praktek di beberapa negara menunjukkan bahwa dinamika perkembangan teknologi yang demikian pesat direspon secara lamban dalam hal penyesuaiannya terhadap perlindungan atas hak warga negara dalam konstitusi. ${ }^{20}$ Alasannya adalah bahasa konstitusi disusun dalam makna yang luas, termasuk cakupan mengenai hak-hak konstitusional. Hal ini dimaksudkan agar hak-hak konstitusional dapat ditafsirkan untuk menyesuaikan diri dengan dinamika perubahan masyarakat.21 Salah satunya, adalah menemukan hak yang tersirat dalam UUD sebagai hak konstitusional.

\section{Hak Asasi dalam UUD 1945}

Dalam sejarah, pencantuman hak asasi dalam konstitusi memiliki perdebatan panjang sebagaimana tercermin dalam catatan sejarah konstitusi yang pernah berlaku di Indonesia. ${ }^{22}$ Ketika Indonesia kembali mengadopsi UUD 1945 sejak berkuasanya Orde Baru pada tahun 1966, muatan hak asasi manusia yang terkandung dalam UUD 1945 dianggap sumir. Muatan hak asasi manusia dalam UUD 1945 bergantung pada konfigurasi politik yang berkuasa. ${ }^{23}$ Bila konfigurasi politik di bawah penguasa demokratis maka hak asasi manusia mendapat tempat yang terhormat. Begitu sebaliknya, hak asasi manusia akan terinjak-injak di bawah kepemimpinan otoritarian. Tesis ini selaras dengan tiga karakteristik hukum di mana terdapat hukum represif (repressive law); hukum mandiri (autonomous law); dan hukum responsif (responsive

\footnotetext{
18 David S. Law, "Globalisation and The Future of Constitutional Rights", artikel dalam Northwestern University Law Review, Vol. 102, No. 3, 2008, hlm. 1307

${ }^{19}$ Nico van Eijk, "Search Engines: Seek and Ye Shall Find? The Position of Search Engines in Law", artikel dalam IRIS plus Legal Observations of the European Audiovisual Observatory, Issue 2006-02, hlm. 5

${ }^{20}$ Ronald E. Leenes et.al (eds), Constitutional Rights and New Technologies: A Comparative Study, TMC Asser Press, The Hague, 2008, hlm. 267

${ }^{21} \mathrm{Ibid}$, hlm. 266

${ }^{22}$ Mahda El-Muhtaj, Hak Asasi Manusia dalam Konstitusi Indonesia, Penerbit Kencana, Jakarta, 2005, hlm 94118; Lihat juga Bagir Manan dan Susi Dwi Harijanti, Op.Cit., hlm. 462-462

${ }_{23}$ Moh. Mahfud MD, Politik. Hukum di Indonesia, LP3ES, Jakarta, 1998, hlm. 107.
} 
law). ${ }^{24}$ Faktanya, hak asasi manusia pada masa Orde Baru mengalami masa kelam di mana pelanggaran hak asasi manusia banyak terjadi di Indonesia.

Seiring dengan bergantinya rezim pemerintahan, ditambah dengan adanya agenda Amendemen Undang-Undang Dasar 1945, jaminan atas penghormatan dan perlindungan hak asasi manusia menjalani babak baru. Perubahan UUD memuat bagian khusus yang mengatur perlindungan dan jaminan atas hak asasi warga negara (Bab XA, Pasal 28A sampai dengan 28J UUD 1945). ${ }^{25}$ Selain termuat dalam bagian khusus tersebut, beberapa pasal di luar dari bagian khusus juga memuat perlindungan terhadap hak warga negara sebagai peninggalan dari ketentuan UUD yang tidak diubah. Secara rinci, ada 27 ketentuan dalam UUD 1945 yang memuat perlindungan hak asasi, baik yang termuat dalam bagian khusus maupun beberapa ketentuan yang ada di luar bagian tersebut (tabel 1).

Tabel 1.

Hak asasi manusia yang termuat dalam (Perubahan) UUD 1945

\begin{tabular}{|c|c|c|}
\hline No. & UUD 1945 & Jenis HAM \\
\hline 1. & Pasal 27 ayat (1) & $\begin{array}{l}\text { Kesamaan kedudukan dalam hukum dan } \\
\text { pemerintahan }\end{array}$ \\
\hline 2. & Pasal 27 ayat (2) & Hak atas pekerjaan dan penghidupan yang layak \\
\hline 3. & Pasal 27 ayat (3) & Hak dan wajib ikut serta dalam bela negara \\
\hline 4. & Pasal 28 & $\begin{array}{l}\text { a. Hak berserikat dan berkumpul } \\
\text { b. Hak mengeluarkan pikiran }\end{array}$ \\
\hline 5. & Pasal 28A & Hak untuk hidup dan mempertahankan kehidupan \\
\hline 6. & Pasal 28B ayat (1) & Hak berkeluarga dan berketurunan \\
\hline 7. & Pasal 28B ayat (2) & $\begin{array}{l}\text { Hak anak untuk hidup dan perlindungan atas } \\
\text { kekerasan dan diskriminasi }\end{array}$ \\
\hline 8. & Pasal 28C ayat (1) & $\begin{array}{l}\text { a. Hak aktualisasi } \\
\text { b. Hak memperoleh pendidikan }\end{array}$ \\
\hline 9. & Pasal 28C ayat (2) & $\begin{array}{l}\text { a. Hak untuk memajukan diri } \\
\text { b. Hak membangun masyarakat }\end{array}$ \\
\hline 10. & Pasal 28D ayat (1) & $\begin{array}{l}\text { a. Hak atas pengakuan, jaminan, perlindungan, dan } \\
\text { kepastian hukum yang adil } \\
\text { b. Hak memperoleh perlakuan yang sama di hadapan } \\
\text { hukum }\end{array}$ \\
\hline
\end{tabular}

24 Philippe Nonet dan Philip Selznick, Law and Society in Transition: Towards Responsive Law, Harper Torchbooks, New York, 1978, hlm. 14.

25 Tidak semua bagian mengatur mengenai jaminan hak asasi manusia, beberapa diantaranya mengatur mengenai hak-hak yang tergolong sebagai non-derogable rights, kemudian pengaturan mengenai kewajiban negara untuk melindungi, memajukan, menegakkan dan memenuhi hak asasi manusia dan juga pembatasan atas pemenuhan hak asasi manusia, sebagaimana tercantum dalam Pasal 28I ayat (1), (3), (4), (5) dan Pasal 28J ayat (1) dan (2). Bandingkan dengan tabel yang disajikan dalam Satya Arinanto, Hak. Asasi Manusia dalam Transisi Politik di Indonesia, PSHTN FHUI, Jakarta, 2003, hlm. 21-30 


No. UUD $1945 \quad$ Jenis HAM

11. Pasal 28D ayat (2) Hak untuk bekerja dan memperoleh imbalan dan perlakuan yang layak

12. Pasal 28D ayat (3) Hak memperoleh kesempatan yang sama dalam pemerintahan

13. Pasal 28D ayat (4) Hak atas status kewarganegaraan

14. Pasal 28E ayat (1) a. Hak untuk bebas memeluk agama dan beribadat menurut agamanya,

b. Hak memilih pendidikan dan pengajaran,

c. Hak memilih pekerjaan,

d. Hak memilih kewarganegaraan,

e. Hak memilih tempat tinggal di wilayah negara dan meninggalkannya, serta berhak kembali

15. Pasal 28E ayat (2) a. Hak atas kebebasan meyakini kepercayaan,

b. Hak menyatakan pikiran dan sikap

16. Pasal 28E ayat (3) a. Hak atas kebebasan berserikat, berkumpul,

b. Hak mengeluarkan pendapat

17. Pasal 28F

a. Hak untuk berkomunikasi dan memperoleh informasi

b. Hak untuk mencari, memperoleh, memiliki, menyimpan, mengolah, dan menyampaikan informasi

18. Pasal 28G ayat (1) a. Hak atas perlindungan diri pribadi, keluarga, kehormatan, martabat, dan harta benda

b. Hak atas rasa aman dan perlindungan dari ancaman ketakutan

19. Pasal 28G ayat (2) a. Hak untuk bebas dari penyiksaan atau perlakuan yang merendahkan derajat martabat manusia

b. Hak memperoleh suaka politik dari negara lain

20. Pasal 28H ayat (1) a. Hak hidup sejahtera lahir dan batin,

b. Hak bertempat tinggal,

c. Hak mendapatkan lingkungan hidup yang baik dan sehat

d. Hak memperoleh pelayanan kesehatan

21. Pasal $28 \mathrm{H}$ ayat (2) Hak mendapat kemudahan dan perlakuan khusus untuk memperoleh kesempatan dan manfaat yang sama

22. Pasal $28 \mathrm{H}$ ayat (3) Hak atas jaminan sosial

23. Pasal $28 \mathrm{H}$ ayat (4) Hak mempunyai hak milik pribadi

24. Pasal 28I ayat (2) Hak bebas dari perlakuan diskriminatif dan hak mendapatkan perlindungan terhadap perlakuan diskriminatif

25. Pasal 29 ayat (2) Merdeka untuk memeluk agamanya masing-masing dan untuk beribadat 


\begin{tabular}{lll}
\hline No. & \multicolumn{1}{c}{ UUD 1945 } & \multicolumn{1}{c}{ Jenis HAM } \\
\hline 26. & Pasal 30 ayat (1) & $\begin{array}{l}\text { Hak dan wajib ikut serta dalam usaha pertahanan dan } \\
\text { keamanan negara }\end{array}$ \\
27. & Pasal 31 ayat (1) & Hak mendapat pendidikan \\
\hline (diolah oleh penulis). &
\end{tabular}

\section{Hak Konstitusional yang Tersirat dalam Pendekatan Praktek di Beberapa Negara}

Di Korea Selatan, pengaturan mengenai hak asasi dan kewajiban warga negara diatur dalam satu bagian tersendiri dalam Konstitusi. ${ }^{26}$ Namun, hak- hak warga negara yang disebutkan dalam Konstitusi bukanlah numerus clausus. Terbukti, bahwa Konstitusi Korea Selatan menyatakan "Freedoms and rights of citizens shall not be neglected on the grounds that they are not enumerated in the Constitution". ${ }^{27}$ Dalam banyak kasus, MK Korea Selatan mempertimbangkan hakhak yang tercantum dalam konvensi internasional meski tidak tercantum dalam Konstitusi. ${ }^{28}$ Meskipun, tidak sedikit juga hak-hak dalam instrumen hukum internasional itu tidak diadopsi karena bertentangan dengan semangat Konstitusi. Misalnya, dalam perkara pengujian konstitusionalitas hak menolak untuk ikut serta dalam wajib militer (the right to conscientious objection). ${ }^{29}$ Perkara ini diajukan oleh sekelompok orang yang tergabung dalam Saksi Yehovah (Jehovah's Witnesses). Dalam ideologi yang dianut kelompok ini, perang adalah suatu hal diharamkan karena bertentangan dengan ajaran kasih sayang yang disebarluaskan oleh kelompok ini. ${ }^{30}$ Sedangkan dalam beberapa peraturan perundang-undangan yang berlaku di Korea Selatan, negara mewajibkan setiap orang untuk wajib militer serta berlaku ancaman pidana bagi mereka yang menolaknya. ${ }^{31}$ Pemberlakuan wajib militer ini bertentangan dengan ajaran Saksi Yehovah dan telah banyak anggota Saksi Yehovah yang menjalani sanksi pidana akibat aturan ini.

\footnotetext{
${ }^{26}$ Bab II Konstitusi Korea Selatan (Pasal 10 sampai dengan Pasal 39)

${ }^{27}$ Pasal 37 ayat (1) Konstitusi Korea Selatan

${ }^{28}$ Yoon Jin Shin, "Contextualized Cosmopolitanism: Human Rights Practice in South Korea", artikel dalam Discussion Paper SP IV 2017-801, diunduh dari https://bibliothek.wzb.eu/pdf/2017/iv17-801.pdf

${ }_{29}$ Putusan Mahkamah Konstitusi Korea Selatan Nomor 2008 Hun-Ga 22 (diterbitkan pada 30 Agustus 2011).

30 “Why Don't Jehovah's Witnesses Go to War?” Diunduh dari https://www.jw.org/en/jehovahswitnesses/faq/why-dont-you-go-to-war/

${ }^{31}$ Lihat UU Korea Selatan tentang Establishment of Homeland Reserve Forces Act (sebelum diubah dengan Act No. 9945 pada 25 Januari 2010), dan Military Service Act (sebelum diubah dengan Act No. 9754 pada 9 Juni 2009)
} 
Hak menolak untuk ikut serta dalam wajib militer merupakan bagian dari kebebasan menjalankan kepercayaan (freedom of conscience). Hak ini merupakan hak asasi yang diakui dalam Konstitusi Korea Selatan ${ }^{32}$ dan International Covenant on Civil and Political Rights, ${ }^{33}$ di mana Korea Selatan merupakan salah satu negara yang menandatangani Konvensi tersebut. Di sebagian besar negara Eropa, hak menolak untuk ikut wajib militer atas dasar kepercayaan telah diakui dan dilindungi. ${ }^{34}$

Dalam putusannya, MK Korea Selatan mempertimbangkan bahwa hak menolak untuk ikut serta dalam wajib militer tidak tergolong sebagai hak konstitusional meskipun beberapa instrumen hukum internasional mengakui dan melindunginya. ${ }^{35}$ Pendekatan yang dilakukan oleh MK Korea Selatan dalam mengakui dan melindungi hak-hak yang tidak tercantum dalam Konstitusi adalah dengan melihat pada instrumen hukum internasional.

Di negara-negara Common Law, lembaga peradilan yang memutuskan untuk mengangkat status suatu hak menjadi hak konstitusional merupakan suatu hal yang kontroversial. Australia yang memiliki Konstitusi sendiri, namun pengaruh tradisi common law masih kental. Pengaruhnya dapat terlihat dari bagaimana Konstitusi Australia (the Commonwealth of Australia Constitutional Act 1900) mengatur mengenai hak-hak asasi yang dimiliki warga negaranya. ${ }^{36}$ Konstitusi Australia juga hanya menyebutkan beberapa hak yang tergolong sebagai hak-hak dasar warga negara (express rights), yaitu hak memperoleh peradilan berdasarkan

${ }^{32}$ Lihat Pasal 19 Konstitusi Korea Selatan yang menyatakan "All citizens shall enjoy freedom of conscience."

${ }^{33}$ Lihat Pasal 18 ICCPR yang menyatakan "(1) Everyone shall have the right to freedom of thought, con science and religion. This right shall include freedom to have or to adopt a religion or belief of his choice, and freedom, either individually or in community with others and in public or private, to manifest his religion or belief in worship, observance, practice and teaching; (2) No one shall be subject to coercion which would impair his freedom to have or to adopt a religion or belief of his choice; (3) Freedom to manifest one's religion or beliefs may be subject only to such limitations as are prescribed by law and are necessary to protect public safety, order, health, or morals or the fundamental rights and freedoms of others."

${ }^{34}$ Marc Stolwijk, "The Right to Conscientious Objection in Europe: A Review of the Current Situation", Brussel: Quaker Council for European Affairs, 2005, http://www.refworld.org/pdfid/42b141794.pdf, diakses tanggal 2 Mei 2017.

35 Decisions of the Korean Constitutional Court 2011, [Putusan Nomor 2007Hun-Ka12 dan 2009Hun-Ba103 (terkonsolidasi), dikeluarkan pada 30 Agustus 2011], hlm 275-280; Lihat juga [Putusan Nomor, 2008Hun-Ka22, 2009Hun-Ka7, 2010Hun-Ka16, 2008Hun-Ba103, 2009Hun-Ba3, dan 2011Hun-Ba16 (terkonsolidasi), dikeluarkan pada 30 Agustus 2011], hlm 281-286. Dapat diunduh melalui situs http://english.ccourt.go.kr/cckhome/ eng/constcourtlib/publications/casePublications.do

${ }^{36}$ George Williams, "The Australian Constitution and Human Rights: A Centenary View”, ANU Research Publications, 2001 https://openresearch-repository.anu.edu.au/bitstream/1885/42078/2/Williams.pdf., hlm. 4-6, diakses pada 3 Mei 2017. 
sistem juri (trial by jury), ${ }^{37}$ kemerdekaan beragama, ${ }^{38}$ pengambilalihan hak milik atas dasar yang adil, ${ }^{39}$ hak-hak para pemilih, ${ }^{40}$ larangan perlakuan diskriminatif terhadap warga dari negara bagian yang berbeda, ${ }^{41}$ dan kebebasan berpindah antar negara bagian. ${ }^{42}$

Meskipun hak asasi yang tercantum dalam konstitusi berjumlah sedikit, namun Australia memiliki catatan yang apik mengenai penghormatan dan jaminan perlindungan atas warga negaranya. ${ }^{43}$ Hal ini ditunjang dari komitmen dari lembaga-lembaga negara untuk menjaga stabilitas politik dana penegakan hak dasar warga negara berdasarkan prinsip-prinsip Common Law dan penegakan rule of law. Dalam sistem Common Law, keberadaan lembaga peradilan untuk melindungi hak-hak dasar warga negara memiliki peranan yang teramat penting. Para hakim dalam sistem Common Law dinyatakan sebagai pelindung hak asasi manusia melalui penerapan prinsip-prinsip hukum.

Namun, bukan berarti bahwa upaya hakim untuk melindungi hak-hak warga negara tanpa kendala. Kecenderungan hakim untuk menafsirkan konstitusi berdasarkan apa yang terdapat dalam teks konstitusi menyebabkan perlindungan atas hak-hak warga negara mengalami kejumudan. Hal inilah yang dialami dalam sejarah peradilan di Australia. ${ }^{4}$

Perubahan dari kejumudan terjadi ketika High Court mengeluarkan putusan dalam perkara Australian Capital Television Pty Ltd and Ors v. Commonwealth of

37 Pasal 80 Konstitusi Australia menyebutkan "The trial on indictment of any offence against any law of the Commonwealth shall be by jury, and every such trial shall be held in the State where the offence was committed, and if the offence was not committed within any State the trial shall be held at such place or places as the Parliament prescribes."

${ }^{38}$ Pasal 116 konstitusi Australia menyatakan "The Commonwealth shall not make any law for establishing any religion, or for imposing any religious observance, or for probibiting the free exercise of any religion, and no religious test shall be required as a qualification for any office or public trust under the Commonwealth."

${ }^{39}$ Pasal 51(xxxi) Konstitusi Australia menyatakan "the acquisition of property on just terms from any State or person for any purpose in respect of which the Parliament has power to make laws"

${ }^{40}$ Pasal 41 Konstitusi Australia menyatakan "No adult person who has or acquires a right to vote at elections for the more numerous House of the Parliament of a State shall, while the right continues, be prevented by any law of the Commonwealth from voting at elections for either House of the Parliament of the Commonwealth."

${ }^{41}$ Pasal 117 Konstitusi Australia menyatakan "A subject of the Queen, resident in any State, shall not be subject in any other State to any disability or discrimination which would not be equally applicable to bim if he were a subject of the Queen resident in such other State."

42 Lihat Pasal 92 dan 97 Konstitusi Australia

${ }^{43}$ Cheryl Saunders, "The Australian Constitution and Our Rights", Future Justice in 2010, diterbitkan oleh Future Leaders, http://www.futureleaders.com.au/book_chapters/pdf/Future_Justice/Cheryl_Saunders.pdf, hlm 117, diakses pada 5 Mei 2017.

44 Timothy H. Jones, "Legal Protection for Fundamental Rights and Freedoms: European Lessons for Australia?”, artikel dalam Federal Law Review, Vol. 22, 1994, hlm. 75-76 
Australia [No 2]. Dalam putusan ini, mayoritas majelis hakim agung Australia45 bersepakat bahwa konstitusi mengandung jaminan atas kebebasan warga negara untuk berdiskusi mengenai politik dalam ruang publik (freedom of political communication). Hak konstitusional ini secara tersirat berasal dari pandangan bahwa efektivitas sistem pemerintahan menuntut keterlibatan warga negara untuk secara aktif memperbincangkan mengenai jalannya pemerintahan. Oleh karenanya, perlu adanya jaminan perlindungan atas kebebasan warga negara dalam berdiskusi soal pemerintahan. Putusan ini diterbitkan dalam konteks penggunaan iklan layanan publik sebagai bagian dari kampanye politik pada saat pemilu.

Jaminan kebebasan warga negara dalam komunikasi politik yang dilindungi dalam putusan perkara Australian Capital Television mengalami perkembangan dalam putusan-putusan High Court berikutnya. ${ }^{46}$ Perkembangan dimaksud salah satunya adalah dalam kaitannya antara kebebasan berkomunikasi politik dengan tuduhan pencemaran nama baik (defamation). ${ }^{47}$

Penafsiran High Court mengenai implied rights dalam beberapa kasus di atas tidak tanpa kritik. Konstitusi Australia dianggap sebagai Konstitusi yang memiliki kedudukan lemah dalam hal perlindungan terhadap hak warga negara, secara tekstual maupun dari pendekatan historis. ${ }^{48}$ Oleh karenanya, penafsiran High Court dengan mengungkapkan adanya hak-hak konstitusional yang tersirat (implied rights) hanya akan memunculkan kontroversi. Dalam pandangan kritikus, pertimbangan High Court untuk menggunakan metode penafsiran positivistik dengan pendekatan pada teks dan sistematika konstitusi semata hanya akan membuat hak untuk berkomunikasi politik menjadi kaku. ${ }^{49}$ Sejatinya, High Court

${ }^{45}$ Disebutkan mayoritas sebab pendapat majelis hakim terbelah dengan kedudukan pendapat mayoritas berbanding yang menyatakan perbedaan pendapatnya adalah 6:1, di mana Justice Dawson menyatakan berbeda pendapat.

46 George Williams, "The State of Play in the Constitutionally Implied Freedom of Political Discussion and Bans on Electoral Canvassing in Australia", Information and reserach Services, Research Paper, Volume 10, 1996-1997, hlm 3-6; Lihat kasus Theophanous v Herald \& Weekly Times Ltd, (182 CLR 104.) Stephens v West Australian Newspapers Ltd (182 CLR 211) dan Cunliffe v Commonwealth (182 CLR 272)

47 Rupert Burns, "Political Discussion as a Defence to Defamation: Lange v Australian Broadcasting Commission", artikel dalam High Court Review, Vol. 3, 1997, hlm. 8

48 Adrienne Stone, "Australia's Constitutional Rights and the Problem of Interpretive Disagreement", artikel dalam Sydney Law Review, Vol. 27, No. 1, 2005, hlm. 48

${ }_{49}$ Adreinne Stone, "The Limits Of Constitutional Text And Structure: Standards Of Review And The Freedom Of Political Communication", artikel dalam Melbourne University Law Review, Vol. 23, Issue 3, 1999, hlm. 695 
juga harus memperhatikan metode pendekatan lainnya seperti menggunakan metode uji proporsionalitas yang memungkinkan fleksibilitas untuk pengembangan doktrin. ${ }^{50}$

Di Amerika Serikat, kajian mengenai pembidangan jenis hak konstitusional warga negara tidak hanya terdiri atas yang tersurat (express rights) dan yang tersirat (implied rights). Konstitusi Amerika Serikat, menurut sebagian ahli hukum, juga mengindikasikan adanya pembidangan ketiga yaitu hak yang tidak tercantum dalam konstitusi (unenumerated rights). ${ }^{51}$ Randy Barnet mengelompokkan ketiga lapisan hak-hak dasar warga negara bersumber dari penafsiran terhadap Konstitusi Amerika Serikat (Tabel 2). Namun, Mahkamah Agung Amerika Serikat sendiri belum mengonfirmasi adanya tiga lapisan hak asasi dalam Konstitusi. Permasalahannya hanyalah berupa penggunaan istilah yang masih beragam dalam soal hak yang tersirat dalam konstitusi, yaitu antara "implied" dan "unenumerated". Bagi Mahkamah Agung, penafsiran adanya hak warga negara yang tersirat didasarkan pada aturan konstitusional yang menyebutkan "The enumeration in the Constitution, of certain rights, shall not be construed to deny or disparage others retained by the people". 52

Tabel 2.

Tiga Bentuk Hak Asasi Warga Negara dalam Konstitusi Amerika Serikat, menurut Randy Barnett. ${ }^{53}$

\begin{tabular}{|c|c|c|c|}
\hline & Hak Tersurat (express) & $\begin{array}{l}\text { Hak Tersirat } \\
\text { (implied) }\end{array}$ & $\begin{array}{c}\text { Hak Tidak } \\
\text { Tercantum } \\
\text { (unenumerated) }\end{array}$ \\
\hline Sumber : & The Bill of Rights & $\begin{array}{l}\text { Amendemen I s.d } \\
\text { Amendemen VIII }\end{array}$ & $\begin{array}{l}\text { Amendemen IX; } \\
\text { Klausula Imunitas }\end{array}$ \\
\hline Contoh : & $\begin{array}{l}\text { Kebebasan Berpendapat; } \\
\text { Hak atas kepemilikan } \\
\text { senjata; } \\
\text { Hak untuk didampingi } \\
\text { Kuasa; } \\
\text { Kebebasan dari penjatuhan } \\
\text { sanksi yang kejam dan } \\
\text { tidak manusiawi; }\end{array}$ & $\begin{array}{l}\text { Kebebasan } \\
\text { Berserikat; } \\
\text { Hak terdakwa } \\
\text { untuk didampingi } \\
\text { kuasa hukum yang } \\
\text { layak; }\end{array}$ & $\begin{array}{l}\text { Hak atas privasi; } \\
\text { Hak aborsi atas } \\
\text { janin yang belum } \\
\text { tumbuh; }\end{array}$ \\
\hline
\end{tabular}

50 Ibid, hlm. 704

51 Adam Lamparello, "Fundamental Unenumerated Rights Under the Ninth Amendment and the Privileges or Immunities Clause,” artikel dalam Akron Law Review, Vol. 49, Issue 1, 2015, hlm. 181

52 Amendemen ke-9 Konstitusi Amerika Serikat.

${ }^{53}$ Diterjemahkan dari Adam Lamparello, Op. Cit., hlm 182. 
Amerika Serikat yang mengadopsi tradisi Common Law mengakui adanya hak-hak yang tersirat dalam Konstitusi di mana hakim berupaya menggalinya melalui penafsiran. Adanya Amendemen ke-9 dalam Konstitusi Amerika Serikat membuatnya berbeda dengan dasar penafsiran adanya hak konstitusional tersirat sebagaimana di Australia. Dari Amendemen ke-9 perdebatan dari kalangan originalist mengenai maksud dari penyusun Konstitusi. Setidaknya ada lima model pendekatan untuk menangkap maksud dari para penyusun Konstitusi. ${ }^{54}$ Namun, dari beragam model pendekatan itu teks Amendemen ke-9 justru telah jelas tanpa perlu adanya penafsiran, sebagaimana kesimpulan Barnett,

"No elaborate theory or hidden code is required to decipher its words. The Ninth Amendment prohibits constitutional constructions ... that infringe upon the unenumerated, natural, and individual rights retained by the people." 55

\section{Hak untuk Didampingi Kuasa Hukum dan Hak atas Praduga Tak Bersalah}

Setidaknya, ada dua putusan MK yang mengkonstruksikan suatu hak menjadi hak konstitusional. Pertama, dalam putusan perkara pengujian UU Advokat, MK menyatakan bahwa

“... hak untuk mendapatkan bantuan hukum, sebagai bagian dari hak asasi manusia, harus dianggap sebagai hak konstitusional warga negara, kendatipun undang-undang dasar tidak secara eksplisit mengatur atau menyatakannya". ${ }^{56}$

Kedua, dalam putusan perkara pengujian UU mengenai Komisi Pemberantasan Korupsi dinyatakan:

"bahwa due process of law dan presumption of innocence merupakan prinsip utama dari negara hukum yang demokratis, ... Prinsip tersebut diakui sebagai hak asasi manusia yang fundamental yang harus dilindungi. Secara implisit hak tersebut diakui dan dapat dikonstruksikan sebagai bagian dari hak asasi manusia dan hak konstitusional yang dijamin dan dilindungi oleh UUD 1945 karenanya harus memperoleh penghormatan, perlindungan, dan pemenuhan secara efektif." 57

\footnotetext{
${ }^{54}$ Randy E. Barnett, “The Ninth Amendment: It Means What It Says”, artikel dalam Texas Law Review, Vol. 85 , No. 1, 2006, hlm. 3

55 Ibid., hlm. 80

56 Putusan MK Nomor 006/PUU-II/2004 tentang Pengujian Undang-Undang Nomor 18 Tahun 2003 tentang Advokat, hlm. 29

57 Putusan MK Nomor 133/PUU-VII/2009 tentang Pengujian Undang-Undang Nomor 30 Tahun 2002 tentang Komisi Pemberantasan Tindak Pidana Korupsi, hlm. 66-69
} 
Simon Butt, dalam penelitian disertasinya, yang pertama kali mengemukakan adanya pertimbangan putusan MK mengenai adanya hak konstitusional tersirat (implied rights). ${ }^{58} \mathrm{Hal}$ ini ditegaskan sebagai salah satu cara yang ditempuh oleh MK untuk memperluas pemberian akses kepada warga negara dalam lingkup kewenangan pengujian undang-undang. 59

Dalam penelitiannya, Butt menyimpulkan bahwa praktek ini banyak dipengaruhi oleh MK Korea Selatan. ${ }^{60}$ Pandangan ini tidak sepenuhnya tepat. MK Korea Selatan memang menggunakan hak-hak yang tidak disebutkan dalam Konstitusi, tetapi tidak semata dalam kewenangan pengujian konstitusionalitas (constitutional review) melainkan lebih banyak dilakukan dalam lingkup kewenangan pengaduan konstitusional (constitutional complaint), 61 sebagaimana ditunjukkan dalam beberapa contoh yang diulas pada bagian di atas.

Hak untuk mendapat bantuan hukum (right to counsel) merupakan bagian dari hak sipil dan politik warga negara sebagaimana tercantum dalam International Covenant on Civil and Political Rights (ICCPR). ${ }^{62}$ Setidaknya, ada 153 negara yang mencantumkan hak untuk mendapatkan bantuan hukum dalam konstitusinya. ${ }^{63}$

Di Indonesia hak untuk mendapatkan bantuan hukum bagi terdakwa diakui sebagai hak yang dilindungi dalam berbagai undang-undang (statutory right) yaitu dalam UU Hak Asasi Manusia, ${ }^{64}$ dan UU Kekuasaan Kehakiman. ${ }^{65}$ Dalam rangka penerapannya, negara berkewajiban menunjuk penasihat hukum untuk memberi

58 Simon Butt, "Judicial Review in Indonesia: Between Civil Law and Accountability? A Study of Constitutional Court Decisions 2003-2005," Disertasi (tidak diterbitkan), University of Melbourne, Australia, Desember 2006.

${ }^{59}$ Stewart Fenwick, "Law and Judicial Review in Indonesia", dalam Tom Ginsburg dan Albert HY Chen (eds), Administrative Law and Governance in Asia: Comparative Perspective, Routledge, London, 2009, hlm. 350

${ }^{60}$ Simon Butt, The Constitutional Court and Democracy in Indonesia, Brill Nijhoff, Leiden, 2015, hlm. 145-146

${ }^{61}$ Pembatasan waktu pengajuan permohonan diatur dalam Pasal 69 UU MK Korea yang menyatakan “(1) A constitutional complaint under Article 68 (1) shall be filed within ninety days after the existence of the cause is known, and within one year after the cause occurs: Provided, That a constitutional complaint which is filed after exhausting remedial processes provided by other laws, shall be filed within thirty days after the final decision in the processes is notified; (2) The adjudication on a constitutional complaint under Article 68 (2) shall be filed within thirty days after a denial of a motion to request for review on the constitutionality of the statute is notified."

${ }^{62}$ Pasal 14 paragraf 3 (d) International Covenant on Civil and Political Rights menyatakan "...to defend himself in person or through legal assistance of his own choosing; to be informed, if he does not have legal assistance, of this right; and to have legal assistance assigned to him, in any case where the interests of justice so require, and without payment by him in any such case if he does not have sufficient means to pay for it,"

${ }^{63}$ Zachary Elkins, James Melton, Tom Ginsburg, "Comparative Constitution Project". Diakses melalui situs https://www.constituteproject.org/ pada tanggal 29 Mei 2017 pukul 11.20 WIB.

${ }^{64}$ Lihat Pasal 18 ayat (4) UU Nomor 39 Tahun 1999 tentang Hak Asasi Manusia

${ }^{65}$ Lihat Pasal 56 UU Nomor 48 Tahun 2009 tentang Kekuasaan Kehakiman 
pelayanan bantuan hukum secara cuma-cuma bagi terdakwa yang tidak mampu. ${ }^{66}$

Aturan ini juga terdapat dalam beberapa peraturan perundang-undangan lainnya. ${ }^{67}$ Aturan mengenai pemberian bantuan hukum ini sangatlah ketat sehingga bila tidak dipenuhi maka akan berakibat pada tidak diterimanya proses penyidikan maupun penuntutan oleh pengadilan. ${ }^{68}$

Meski telah diakui dan dilindungi dalam peraturan perundang-undangan, namun MK memandang perlu untuk menegaskan hak untuk mendapatkan bantuan hukum sebagai hak konstitusional. Dasar pijakan MK adalah bahwa Indonesia merupakan negara hukum sebagaimana diatur dalam Pasal 1 ayat (3) UUD 1945.69 Landasan yang sama juga menjadi batu pijakan MK dalam menyatakan praduga tak bersalah sebagai hak konstitusional.

Due process of law dapat diterjemahkan tidak hanya sebagai prinsip, namun juga hak seseorang, dalam rangka memperoleh perlakuan yang adil dan setara serta dapat mengikuti proses peradilan yang efektif. ${ }^{70} \mathrm{Hal}$ ini tergambar sebagai

${ }^{66}$ Pasal 56 ayat (1) dan (2) UU nomor 8 Tahun 1981 tentang Hukum Acara Pidana menyatakan bahwa “(1) Dalam hal tersangka atau terdakwa disangka atau didakwa melakukan tindak pidana yang diancam dengan pidana mati atau ancaman pidana lima belas tabun atau lebih atau bagi mereka yang tidak. mampu yang diancam dengan pidana lima tabun atau lebih yang tidak mempunyai penasihat bukum sendiri, pejabat yang bersangkutan pada semua tingkat pemeriksaan dalam proses peradilan wajib menunjuk penasihat bukum bagi mereka.; (2) Setiap penasibat bukum yang ditunjuk untuk bertindak sebagaimana dimaksud dalam ayat (1), memberikan bantuannya dengan cuma-cuma."

${ }^{67}$ Lihat Pasal 22 ayat (1) UU Nomor 18 Tahun 2003 tentang Advokat (yang mengatur kewajiban memberi bantuan hukum bagi yang tidak mampu); lihat juga UU Nomor 16 Tahun 2011 tentang Bantuan Hukum serta Peraturan Pemerintah No. 83 Tahun 2008 Tentang Persyaratan dan Tata Cara Pemberian Bantuan Hukum Secara Cuma-Cuma; Sedangkan khusus untuk anak-anak juga diatur dalam Pasal 51 ayat (1) UU No 3 Tahun 1997 tentang Pengadilan Anak yang menyatakan "Setiap Anak Nakal sejak saat ditangkap atau ditahan berbak mendapatkan bantuan bukum dari seorang atau lebib Penasibat Hukum selama dalam waktu dan pada setiap tingkat pemeriksaan menurut tata cara yang ditentukan dalam Undang-undang ini"

${ }^{68}$ Lihat beberapa putusan Mahkamah Agung, diantaranya:

- Putusan Mahkamah Agung RI No 1565 K/Pid/1991 tertanggal 16 September 1993 yang menyatakan pada pokoknya, "apabila syarat - syarat permintaan tidak dipenubi seperti halnya penyidik tidak menunjuk penasibat bukum bagi Tersangka sejak awal penyidikan, maka tuntutan penuntut umum dinyatakan tidak dapat diterima."

- Putusan Mahkamah Agung RI dengan No 367 K/Pid/1998 tertanggal 29 Mei 1998 yang menyatakan "babwa bila tak didampingi oleh penasibat bukum di tingkat penyidikan maka bertentangan dengan Pasal 56 KUHAP, hingga BAP penyidikan dan penuntut umum batal demi bukum dan karenanya tuntutan penuntut umum tidak dapat diterima, walaupun pemeriksaan di sidang pengadilan di dampingi penasihat bukum."

- Putusan MA No 545 K/Pid.Sus/2011 menegaskan "Babwa selama pemeriksaan Terdakwa tidak didampingi oleh Penasehat Hukum, sedangkan Berita Acara Penggeledahan dan Pernyataan tanggal 15 Desember 2009 ternyata telah dibuat oleh Pejabat yang tidak melakukan tindakan tersebut namun oleh petugas yang lain; Dengan demikian Berita Acara Pemeriksaan Terdakwa, Berita Acara Penggeledahan tidak sah dan cacat hukum sehingga surat Dakwaan Jaksa yang dibuat atas dasar Berita Acara tersebut menjadi tidak sab dan cacat hukum pula"

69 Putusan MK Nomor 006/PUU-II/2004 tentang Pengujian Undang-undang Republik Indonesia Nomor 18 Tahun 2003 tentang Advokat, hlm. 29

70 Icelandic Human Rights Centre, http://www.humanrights.is/en/human-rights-educationproject/human-rights-concepts-ideas-and-fora/substantive-human-rights/the-right-to-due-process diakses pada 10 Mei 2017. 
bagian dari hak untuk memperoleh keadilan yang dijamin dalam Pasal 28D ayat (1) UUD 1945.71 Namun, UUD 1945 tidak menyebutkan adanya perlindungan atas hak atas praduga tak bersalah (presumption of innocence). Hak untuk dianggap tidak bersalah justru banyak tersebar dalam peraturan perundang-undangan sebagai statutory rights. ${ }^{72}$ Meskipun demikian, MK menyatakan bahwa hak tersebut merupakan hak konstitusional dengan merujuk pada Pasal 1 ayat (3) UUD 1945.

Secara singkat, hak untuk memperoleh bantuan hukum dan hak untuk dianggap tidak bersalah menjadi hak konstitusional yang dijamin oleh UUD 1945 merupakan hasil penafsiran MK mengenai "negara hukum" sebagaimana tercantum dalam Pasal 1 ayat (3) UUD 1945.

Asal muasal pemuatan konsep "negara hukum" adalah pada Penjelasan UUD 1945, di mana disebutkan bahwa "Indonesia, ialah negara yang berdasar atas Hukum (Rechtsstaat)". Dalam Penjelasan UUD 1945, "negara hukum" disandingkan berlawanan dengan negara berdasar atas kekuasaan belaka (Machtsstaat). Konsep "negara hukum" kemudian diadopsi dalam batang tubuh UUD sebagai hasil dari rumusan Perubahan UUD 1945 yang menghapuskan bagian Penjelasan UUD 1945. Secara teori, konsep "negara hukum" terlahir sebagai respon dari konsep "negara polisi" (polizeistaat) di mana raja berkuasa untuk menentukan segala sesuatunya dan rakyat tidak memiliki kedaulatan. ${ }^{73}$

Banyak sarjana maupun konferensi akademis yang berupaya merumuskan unsur-unsur pokok yang menjadi syarat sebuah "negara hukum", baik dalam rumusan kriteria yang bersifat umum maupun rumusan khusus mengenai negara hukum versi Indonesia. Salah satunya yang dikemukakan oleh Abdul Mukthie Fadjar mengenai "Negara Hukum Pancasila". Menurutnya, negara hukum

${ }^{71}$ Putusan MK Nomor 133/PUU-VII/2009 tentang Pengujian Undang-Undang Nomor 30 Tahun 2002 tentang Komisi Pemberantasan Tindak Pidana Korupsi, hlm. 68

${ }^{72}$ Lihat Pasal 8 UU Nomor 4 tahun 2004 tentang Kekuasaan Kehakiman yang berbunyi, "Setiap orang yang disangka, ditangkap, ditahan, dituntut dan/atau dihadapkan di depan pengadilan wajib dianggap tidak bersalab sebelum ada putusan pengadilan yang menyatakan kesalahannya dan telah memperoleh kekuatan bukum tetap"; Lihat juga Penjelasan Umum UndangUndang Nomor 8 Tahun 1981 tentang Hukum Acara Pidana (KUHAP) angka 3 huruf c; Serta Pasal 18 ayat (1) UU Nomor 39 Tahun 1999 tentang Hak Asasi Manusia yan menyatakan "Setiap orangyang ditangkap, ditahan, dan dituntut karena disangka melakukan sesuatu tindak pidana berhak dianggap tidak bersalah, sampai dibuktikan kesalahannya secara sah dalam suatu sidang pengadilan..."

73 Susi Dwi Harijanti, "Negara Hukum Dalam UUD 1945” dalam Susi Dwi Harijanti, et. al (eds), Negara Hukum Yang Berkeadolan: Kumpulan Pemikiran Dalam Rangka Purnabakti Prof. Dr. Bagir Manan, S.H., MCL, Bandung: Rosda-PSKN HTN Unpad, 2011, hlm 79-99; Lihat juga Azhary, Negara Hukum Indonesia: Analisis Yuridis Normatif tentang Unsur-Unsurnya, UI-Press, Jakarta, 1995, hlm. 44-45 
Pancasila adalah konsep negara hukum dimana satu pihak harus memenuhi kriteria konsep negara hukum pada umumnya dan di lain pihak, diwarnai oleh aspirasi keindonesiaan yaitu lima nilai fundamental Pancasila. ${ }^{74}$ Mahfud MD berpendapat, bahwa konsepsi negara hukum yang diadopsi dalam UUD 1945 setelah Perubahan dianggap menjadi "lebih terbuka" tanpa adanya penyebutan istilah asing yang menyertainya, seperti rechtstaat atau rule of law. ${ }^{75}$

I Dewa Gede Palguna merangkumkan tiga ciri khas substansial yang wajib dipenuhi dalam konsep "negara hukum" yaitu: (i) kekuasaan pemerintah dibatasi oleh hukum; (ii) legalitas formal; dan (iii) hukum yang memerintah, bukan manusia.76 Kesimpulan ini diperjelas dengan keterangan bahwa para perumus Perubahan UUD 1945, memiliki kecenderungan menguatnya pandangan positivistik dimana untuk mengakomodasi asas konstitusionalisme diperlukan adanya aturan jaminan perlindungan hak asasi yang lebih lengkap. ${ }^{77}$ Oleh karenanya, hak konstitusional digunakan sebagai ukuran untuk membatasi kekuasaan pemerintahan.

Penafsiran mengenai unsur-unsur negara hukum semestinya tidak serta merta melegitimasi semua hak-hak asasi yang tidak tercantum dalam UUD menjadi hak konstitusional. Indonesia telah memiliki UU yang mengatur mengenai hak asasi manusia secara terperinci dan juga telah meratifikasi instrumen internasional yang memuat hak-hak asasi. Hak-hak yang termuat dalam berbagai UU tersebut tidak semestinya dapat dianggap sebagai hak konstitusional dengan berlandaskan pada penafsiran mengenai konsep "negara hukum".

MK perlu menerapkan metode penafsiran yang lebih tepat dalam mengangkat status hak konstitusional yang tersirat. Pendekatan yang dilakukan Amerika Serikat tidak bisa menjadi rujukan sebab Konstitusi Amerika Serikat membuka pintu adanya hak yang tersirat, berdasarkan penafsiran dari Amendemen ke-9. Praktek di Korea Selatan patut untuk dilihat secara lebih mendalam sebab Konstitusi Korea Selatan memiliki karakteristik yang sama

\footnotetext{
${ }^{74}$ Abdul Mukthie Fadjar, Sejarah, Elemen dan Tipe Negara Hukum, Setara Press, Malang, 2016, hlm. 68

${ }^{75}$ Mahfud MD, "Rambu Pembatas dan Perluasan Kewenangan Mahkamah Konstitusi”, artikel dalam Jurnal Hukum Ius Quia Iustum, Vol. 16, No.4 Oktober 2009, hlm. 443

${ }^{76}$ I Dewa Gede Palguna, Op. Cit., hlm. 93-94 hlm. 202

77 Ahsin Thohari, Hak Konstitusional dalam Hukum Tata Negara Indonesia, Penerbit Erlangga, Jakarta, 2016,
} 
dengan UUD 1945. Aturan mengenai hak asasi disebutkan secara terperinci dalam Konstitusi Korea Selatan. Namun, MK Korea Selatan membuka kemungkinan untuk mengadopsi hak-hak asasi yang tidak disebutkan dalam Konstitusi dengan mempertimbangkan pada hak-hak fundamental yang tencantum pada instrumen internasional. ${ }^{78}$ Tidak semua hak-hak fundamental dalam instrumen internasional tersebut lantas diadopsi menjadi hak konstitusional. Terdapat pertimbangan relativitas budaya yang perlu menjadi perhatian penting. Seperti dalam kasus Saksi Yehovah, MK Korea Selatan tidak serta merta mengadopsi hak untuk menolak ikut serta dalam wajib militer karena hak tersebut tercantum dalam instrumen internasional dan menjadi hak konstitusional yang disebutkan dalam Konstitusi di beberapa negara Eropa. Pengadopsian hak untuk menolak ikut serta dalam wajib militer masih dipandang belum dapat diterima di Korea Selatan karena pertimbangan kondisi politik dan budaya yang ada.

Pada praktek penerapannya, pertimbangan untuk menggunakan hak konstitusional yang tersirat merupakan sesuatu hal yang masih langka. Hanya ada dua putusan yang mempertimbangkan menggunakan hak konstitusional yang tersirat sebagai batu uji. Meski telah menjadi hak konstitusional, hak untuk didampingi kuasa hukum serta hak atas praduga tidak bersalah tidak menjadi doktrin yang digunakan untuk menguji konstitusionalitas dalam putusan-putusan selanjutnya. Belum ada satu putusan yang menguji adanya pelanggaran atas kedua hak konstitusional yang tersirat tersebut. Pada satu kesempatan, MK pernah menguji UU Bantuan Hukum ${ }^{79}$ di mana pengujian norma ini bergesekan dengan hak konstitusional untuk memperoleh bantuan hukum. Namun, dalam putusannya MK tidak menyinggung adanya hak untuk memperoleh bantuan hukum sebagai hak konstitusional yang pernah disebutkan dalam putusan sebelumnya.

\section{Penutup}

Praktek MK dalam menetapkan hak konstitusional yang tersirat sebagai batu uji dalam perkara pengujian UU bukanlah hal yang baru, meskipun masih sangat

\footnotetext{
${ }^{78}$ Wen, Chen Chang, “The Convergence of Constitutions and International Human Rights: Taiwan and South Kore in Comaparison, artikel dalam North Carolina Journal of International Law and Commmercial Regulations, Vol 36, No. 3, 2011, hlm. 596

79 Putusan MK Nomor 88/PUU-X/2012 tentang Pengujian Undang-Undang Nomor 16 Tahun 2011 tentang Bantuan Hukum, diputus pada tanggal 19 Desember 2013.
} 
langka. Hanya ada dua putusan dengan dua hak yang ditetapkan sebagai hak konstitusional yang tersirat, yaitu hak untuk didampingi kuasa hukum dan hak atas praduga tak bersalah.

Penggunaan hak yang tersirat dalam pengujian konstitusionalitas UU tidaklah semata dipandang sebagai bentuk perluasan pemberian akses kepada warga negara dalam rangka mengajukan perkara judicial review. Penetapan hak konstitusional yang tersirat, salah satu tujuannya, adalah dalam rangka memberi kepastian pada perlindungan hak warga negara dalam negara hukum sebagaimana diatur dalam Pasal 1 ayat (3) UUD 1945. Selain itu, Pembukaan Universal Declaration of Human Rights juga menyatakan bahwa "human rights should be protected by the rule of law". Dalam penafsiran MK, hak untuk didampingi kuasa hukum dan hak atas praduga tak bersalah merupakan hak konstitusional yang disarikan dari prinsip negara hukum. Pendekatan yang dilakukan MK dalam memberi status hak konstitusional terhadap kedua hak tersebut lebih menggunakan principle-based reasoning. Negara hukum sebagai sebuah prinsip yang termaktub dalam UUD 1945 dielaborasi melalui penafsiran konstitusi oleh MK dalam bentuk memberi status hak konstitusional pada hak yang sejatinya adalah statutory rights.

\section{Daftar Pustaka}

\section{Buku}

Arinanto, Satya, Hak Asasi Manusia dalam Transisi Politik di Indonesia, PSHTN FHUI, Jakarta, 2003.

Azhary, Negara Hukum Indonesia: Analisis Yuridis Normatif tentang Unsur-Unsurnya, UI-Press, Jakarta, 1995.

Butt, Simon, The Constitutional Court and Democracy in Indonesia, Brill Nijhoff, Leiden, 2015.

El-Muhtaj, Mahda, Hak Asasi Manusia dalam Konstitusi Indonesia, Penerbit Kencana, Jakarta, 2005.

Fadjar, Abdul Mukthie, Sejarah, Elemen dan Tipe Negara Hukum, Setara Press, Malang, 2016.

Fenwick, Stewart, "Law and Judicial Review in Indonesia”, dalam Tom Ginsburg dan Albert HY Chen (eds), Administrative Law and Governance in Asia: Comparative Perspective, Routledge, London, 2009. 
Harijanti, Susi Dwi, “Negara Hukum Dalam UUD 1945” dalam Susi Dwi Harijanti, et. al (eds), Negara Hukum Yang Berkeadolan: Kumpulan Pemikiran Dalam Rangka Purnabakti Prof. Dr. Bagir Manan, S.H., MCL, Bandung: Rosda-PSKN HTN Unpad, 2011.

Leenes, Ronald E., et.al (eds), Constitutional Rights and New Technologies: A Comparative Study, TMC Asser Press, The Hague, 2008.

Mahfud MD, Moh., Politik Hukum di Indonesia, LP3ES, Jakarta, 1998.

Nonet, Philippe dan Selznick, Philip, Law and Society in Transition: Towards Responsive Law, Harper Torchbooks, New York, 1978.

Palguna, I Dewa Gede, Pengaduan Konstitusional: Upaya Hukum Terhadap Pelanggaran Hak-Hak Konstitusional Warga Negara, Jakarta: Penerbit Sinar Grafika, 2013.

Soemantri, Sri, Bunga Rampai Hukum Tata Negara Indonesia, Alumni, Bandung, 1992.

Thohari, Ahsin, Hak Konstitusional dalam Hukum Tata Negara Indonesia, Penerbit Erlangga, Jakarta, 2016.

\section{Hasil Penelitian}

Butt, Simon, "Judicial Review in Indonesia: Between Civil Law and Accountability? A Study of Constitutional Court Decisions 2003-2005," Disertasi (tidak diterbitkan), University of Melbourne, Australia, Desember 2006.

Williams, George, "The State of Play in the Constitutionally Implied Freedom of Political Discussion and Bans on Electoral Canvassing in Australia", Information and reserach Services, Research Paper, Volume 10, 1996-1997.

van Eijk, Nico, "Search Engines: Seek and Ye Shall Find? The Position of Search Engines in Law", IRIS plus Legal Observations of the European Audiovisual Observatory, Issue 2006-02.

\section{Jurnal}

Barnett, Randy E. “The Ninth Amendment: It Means What It Says", Texas Law Review, Vol. 85, No. 1, 2006.

Burns, Rupert, "Political Discussion as a Defence to Defamation: Lange v Australian Broadcasting Commission", High Court Review, Vol. 3, 1997.

Gardbaum, Stephen, "Human Rights as International Constitutional Rights", The European Journal of International Law, Vol 19, No. 4, 2008.

“The 'Horizontal' Effect of Constitutional Rights", Michigan Law Review, Vol. 102, 2003.

Jones, Timothy H., "Legal Protection for Fundamental Rights and Freedoms: European Lessons for Australia?" Federal Law Review, Vol. 22, 1994.

Lamparello, Adam, "Fundamental Unenumerated Rights Under the Ninth Amendment and the Privileges or Immunities Clause," Akron Law Review, Vol. 49, Issue 1, 2015. 
Law, David S., "Globalisation and The Future of Constitutional Rights", Northwestern University Law Review, Vol. 102, No. 3, 2008.

Mahfud MD, Moh., "Rambu Pembatas dan Perluasan Kewenangan Mahkamah Konstitusi", Jurnal Hukum Ius Quia Iustum, Vol. 16, No.4 Oktober 2009.

Manan, Bagir Manan dan Susi Dwi Harijanti, "Konstitusi dan Hak Asasi Manusia”, Padjadjaran Jurnal Ilmu Hukum, Vol. 3 No. 32016.

Neuman, Gerald L., "Human Rights and Constitutional Rights: Harmony and Dissonance", Stanford Law Review, Vol. 55, No. 5, 2003.

Stone, Adrienne, "Australia's Constitutional Rights and the Problem of Interpretive Disagreement", Sydney Law Review, Vol. 27, No. 1, 2005.

, "The Limits OfConstitutional Text And Structure: Standards Of Review And The Freedom Of Political Communication", Melbourne University Law Review, Vol. 23, Issue 3, 1999.

\section{Makalah}

Asshiddiqie, Jimly, "Hak Konstitusional Perempuan dan Tantangan Penegakannya", Makalah pada Dialog Publik dan Konsultasi Nasional "Perempuan dan Konstitusi di era otonomi Daerah: Tantangan dan Penyikapan Bersama" diselenggarakan oleh Komnas Perempuan, Jakarta, 27 Nopember 2007.

\section{Internet}

Icelandic Human Rights Centre, http://www.humanrights.is/en/human-rightseducation-project/human-rights-concepts-ideas-and-fora/substantivehuman-rights/the-right-to-due-process diakses pada 10 Mei 2017.

Jin Shin, Yoon, "Contextualized Cosmopolitanism: Human Rights Practice in South Korea", Discussion Paper SP IV 2017-801, diunduh dari https://bibliothek.wzb.eu/pdf/2017/iv17-801.pdf diakses pada 10 Mei 2017

Saunders, Cheryl, "The Australian Constitution and Our Rights", Future Justice in 2010, http://www.futureleaders.com.au/book_chapters/pdf/Future_ Justice/Cheryl_Saunders.pdf, diakses pada 5 Mei 2017.

Stolwijk, Marc, "The Right to Conscientious Objection in Europe: A Review of the Current Situation", Brussel: Quaker Council for European Affairs, 2005, http://www.refworld.org/pdfid/42b141794.pdf, diakses tanggal 2 Mei 2017.

"Why Don't Jehovah's Witnesses Go to War?", https:/ /www.jw.org/en/jehovahswitnesses/faq/why-dont-you-go-to-war/, diakses pada 12 Mei 2017

Williams, George, "The Australian Constitution and Human Rights: A Centenary View", ANU Research Publications, 2001 https://openresearchrepository.anu.edu.au/bitstream/1885/42078/2/Williams.pdf., diakses pada 3 Mei 2017. 
Zachary Elkins, James Melton, dan Tom Ginsburg, "Comparative Constitution Project". https://www.constituteproject.org/, diakses pada 11 Mei 2017.

\section{Peraturan Perundang-undangan}

Undang-Undang Nomor 8 Tahun 2011 tentang Perubahan Undang-Undang Nomor 24 Tahun 2003 tentang Mahkamah Konstitusi, Lembaran Negara Republik Indonesia Tahun 2011 Nomor 70, Tambahan Lembaran Negara Republik Indonesia Nomor 5226.

Undang-Undang Nomor 3 Tahun 2009 tentang Perubahan Kedua Atas UndangUndang Nomor 14 Tahun 1985 tentang Mahkamah Agung, Lembaran Negara Republik Indonesia Tahun 2009 Nomor 3, Tambahan Lembaran Negara Republik Indonesia Nomor 4958.

Undang-Undang Nomor 39 Tahun 1999 tentang Hak Asasi Manusia, Lembaran Negara Republik Indonesia Tahun 1999 Nomor 165, Tambahan Lembaran Negara Republik Indonesia Nomor 3886;

Undang-Undang Nomor 26 Tahun 2000 tentang Pengadilan Hak Asasi Manusia, Lembaran Negara Republik Indonesia Tahun 2000 Nomor 208, Tambahan Lembaran Negara Republik Indonesia Nomor 4026.

Undang-Undang Nomor 11 Tahun 2005 tentang Pengesahan International Covenant On Economic, Social And Cultural Rights (Kovenan Internasional Tentang Hak-Hak Ekonomi, Sosial Dan Budaya), Lembaran Negara Republik Indonesia Tahun 2005 Nomor 118, Tambahan Lembaran Negara Republik Indonesia Nomor 4557;

Undang-Undang Nomor 12 Tahun 2005 tentang Pengesahan International Covenant On Civil And Political Rights (Kovenan Internasional Tentang Hak-Hak Sipil Dan Politik), Lembaran Negara Republik Indonesia Tahun 2005 Nomor 119, Tambahan Lembaran Negara Republik Indonesia Nomor 4558;

Undang-Undang Nomor 29 Tahun 1999 tentang Pengesahan International Convention On The Elimination Of All Forms Of Racial Discrimination 1965 (Konvensi Internasional Tentang Penghapusan Segala Bentuk Diskriminasi Rasial 1965), Lembaran Negara Republik Indonesia Tahun 1999 Nomor 83, Tambahan Lembaran Negara Republik Indonesia Nomor 3852;

Undang-Undang Nomor 7 Tahun 1984 tentang Pengesahan Konvensi Mengenai Penghapusan Segala Bentuk Diskiriminasi Terhadap Wanita (Convention On The Elimination Of All Forms Of Discrimination Against Women), Lembaran Negara Republik Indonesia Tahun 1984 Nomor 29, Tambahan Lembaran Negara Republik Indonesia Nomor 3227;

Undang-Undang Nomor 6 Tahun 2012 tentang Pengesahan International Convention On The Protection Of The Rights Of All Migrant Workers And Members Of Their Families (Konvensi Internasional Mengenai Perlindungan Hak-Hak Seluruh Pekerja Migran Dan Anggota Keluarganya), Lembaran Negara 
Republik Indonesia Tahun 2012 Nomor 115, Tambahan Lembaran Negara Republik Indonesia Nomor 5314;

Undang-Undang Nomor 19 Tahun 2011 tentang Pengesahan Convention On The Rights Of Persons With Disabilities (Konvensi Mengenai Hak-Hak Penyandang Disabilitas), Lembaran Negara Republik Indonesia Tahun 2011 Nomor 107, Tambahan Lembaran Negara Republik Indonesia Nomor 5251.

Undang-Undang Nomor 8 Tahun 1981 tentang Hukum Acara Pidana, Lembaran Negara Republik Indonesia Tahun 1981 Nomor 76, Tambahan Lembaran Negara Republik Indonesia Nomor 3258

Undang-Undang Nomor 18 Tahun 2003 tentang Advokat, Lembaran Negara Republik Indonesia Tahun 2003 Nomor 49, Tambahan Lembaran Negara Republik Indonesia Nomor 4288

Undang-Undang Nomor 16 Tahun 2011 tentang Bantuan Hukum, Lembaran Negara Republik Indonesia Tahun 2011 Nomor 104, Tambahan Lembaran Negara Republik Indonesia Nomor 5248

Undang-Undang Nomor 48 tahun 2009 tentang Kekuasaan Kehakiman, Lembaran Negara Republik Indonesia Tahun 2009 Nomor 157, Tambahan Lembaran Negara Republik Indonesia Nomor 5076

Peraturan Pemerintah No. 83 Tahun 2008 Tentang Persyaratan dan Tata Cara Pemberian Bantuan Hukum Secara Cuma-Cuma, Lembaran Negara Republik Indonesia Tahun 2008 Nomor 214, Tambahan Lembaran Negara Republik Indonesia Nomor 4955

\section{Putusan Pengadilan}

Putusan Mahkamah Konstitusi Nomor 133/PUU-VII/2009 tentang Pengujian Undang-Undang Nomor 30 Tahun 2002 tentang Komisi Pemberantasan Tindak Pidana Korupsi, 29 Oktober 2009

Putusan Mahkamah Konstitusi Nomor 102/PUU-VII/2009 tentang Pengujian Undang-Undang Nomor 42 Tahun 2008 tentang Pemilihan Umum Presiden dan Wakil Presiden, 6 Juli 2009.

Putusan Mahkamah Konstitusi Nomor 85/PUU-X/2012 tentang Pengujian Undang-Undang Nomor 32 Tahun 2004 tentang Pemerintahan Daerah, 5 November 2014

Putusan Mahkamah Konstitusi Nomor 14/PUU-XI/2013 tentang Pengujian Undang-Undang Nomor 42 Tahun 2008 tentang Pemilihan Umum Presiden dan Wakil Presiden, 23 Januari 2014

Putusan Mahkamah Konstitusi Nomor 006/PUU-II/2004 tentang Pengujian Undang-Undang Nomor 18 Tahun 2003 tentang Advokat, 13 Desember 2004 
Putusan Mahkamah Konstitusi Nomor 88/PUU-X/2012 tentang Pengujian Undang-Undang Nomor 16 Tahun 2011 tentang Bantuan Hukum, 19 Desember 2013.

Putusan Mahkamah Konstitusi Nomor 13/PUU-VI/2008 tentang Pengujian Undang-Undang Nomor 16 Tahun 2008 tentang Perubahan Atas UndangUndang Nomor 45 Tahun 2007 tentang Anggaran Pendapatan dan Belanja Negara Tahun Anggaran 2008, 13 Agustus 2008.

Putusan Mahkamah Agung Nomor : 54 P/HUM 2013, tanggal 19 Desember 2013;

Putusan Mahkamah Agung Nomor : 62 P/HUM/2013, tanggal 18 Nopember 2013;

Putusan Mahkamah Agung No 1565 K/Pid/1991 tertanggal 16 September 1993

Putusan Mahkamah Agung No 367 K/Pid/1998 tertanggal 29 Mei 1998 